\title{
Mortality after remote surgery for benign gastroduodenal disease
}

\author{
C C S Staël von Holstein, H Anderson, S B S Eriksson, B Huldt
}

\begin{abstract}
Mortality was studied after partial gastrectomy in a cohort of 1575 patients operated on because of benign gastroduodenal disease 29 to 59 years ago. The final status was confirmed in all but $8 \cdot 4 \%$ of the cohort. At the close of the study $78 \%$ of the traced population were dead. Overall mortality was significantly higher than in the general population of southern Sweden (standardised mortality ratio $=1 \cdot 10 ; 95 \%$ confidence intervals $1 \cdot 03$ to $1 \cdot 17)$. Excess deaths resulted from neoplasms in the stomach, pancreas, male genital organs, and respiratory organs, as well as from respiratory diseases and suicide. Patients operated on before the age of 45 had a $60 \%$ increase in overall mortality during the first 19 years after surgery, mainly because of cardiovascular disease and suicide, whereas among those operated on after this age mortality was comparable to that in the reference population. The $75 \%$ increased death rate in cardiovascular disease during the first 19 years after surgery in patients operated on at young age, dramatically decreased during the years thereafter. An increased risk of death caused by malignancy was apparent more than 20 years postoperatively, irrespective of age at surgery. Excess deaths resulting from gastrointestinal malignancies, mainly gastric and pancreatic carcinoma, outnumbered the increased number of deaths resulting from cancer in the respiratory organs.

(Gut 1995; 37: 617-622)
\end{abstract}

Keywords: peptic ulcer surgery, partial gastric resection, cancer mortality, stomach cancer, pancreatic cancer, respiratory disease.

In 1958 Krause $^{1}$ reported a decreased life expectancy in a cohort of patients operated on during the first three decades of this century for peptic ulcer disease. The main reasons for the increased mortality were tuberculosis, gastric carcinoma, and suicide. Although tuberculosis is a minor problem nowadays, studies on cohorts of ulcer patients operated on more recently have confirmed an increased incidence of suicide ${ }^{2-5}$ and of gastric stump carcinoma after a 15 to 20 year latency period. ${ }^{6-10}$ Increased incidences have also been reported both for carcinomas at other sites 57 11-13 and for smoking related diseases. ${ }^{7} 11-15$ Although this suggests a gloomy outcome for gastrectomy patients, contrasting reports have been published both of unchanged ${ }^{16}$ and even decreased $^{5}$ overall mortality. Decreased mortality in ischaemic heart disease ${ }^{5}$ and in cerebrovascular disease ${ }^{511}$ have also been reported; and as diseases in the circulatory organs account for more than half of the mortality in the general population this may explain why mortality in gastrectomy patients are more or less comparable to that in the general population. ${ }^{5} 17$

With few exceptions, ${ }^{1513}$ previously published studies on mortality after partial gastrectomy have been carried out in cohorts where follow up has been comparatively short and where most of the patients were still alive. $^{2} 1114$ 16-19 This makes conclusions about mortality difficult to draw, as most of these patients are operated on at young ages, and adverse, as well as beneficial, effects of surgery may develop with time. Here we report the outcome in a cohort of patients operated on 29 to 59 years ago, of which $78 \%$ have died, with special attention to the impact on mortality of age at surgery.

\section{Methods}

Data on all patients operated on for benign gastroduodenal disease between 1930 and the end of 1960, at the Department of Surgery, Lund, Sweden, were collected from surgical records and hospital files. The patients were followed up from the date of surgery until death (obtained from parish records) or 31 December 1989 whichever came first. Death certificates were collected for all the deceased, and the cause of death classified according to the 8th revision of the International Classification of Diseases, Injuries, and Causes of Death (ICD). Patients who died of gastric carcinoma within five years after surgery were excluded, as it was assumed that they suffered from gastric carcinoma at the time of operation.

Some 1575 patients were operated on (1287 males and 288 females) for duodenal ulcer $(\mathrm{n}=965 ; 61 \%)$, prepyloric ulcer $(\mathrm{n}=58)$, gastric ulcer $(n=493 ; 31 \%)$ or other miscellaneous diagnoses $(n=59)$. A Billroth I resection was performed in 211 cases $(13 \%)$, and a Billroth II procedure in 1206 cases $(77 \%)$. Three patients were operated on with other types of resections and 155 subjects $(10 \%)$ with a gastroenteroanastomosis. A total of 1422 patients $(91.6 \%)$ could be traced. Those who emigrated or were otherwise lost to follow up were recorded as withdrawn alive the year when they were lost.

Mortality in the cohort was compared with the official death rates for the Southern 
TABLE I Mortality in the total cohort of 1323 persons, constituting 29556 person years, by diagnostic categories

\begin{tabular}{|c|c|c|c|c|c|}
\hline \multirow[b]{2}{*}{ Cause of death } & \multicolumn{2}{|c|}{ Deaths $(n)$} & \multirow[b]{2}{*}{$S M R$} & \multirow{2}{*}{$\begin{array}{l}95 \% \\
\text { Confidence } \\
\text { interval }\end{array}$} & \multirow{2}{*}{$\begin{array}{l}p \text { Value } \\
\text { two sidec }\end{array}$} \\
\hline & Observed & Expected & & & \\
\hline Infectious diseases & 8 & $6 \cdot 42$ & $1 \cdot 25$ & 0.54 to 2.45 & 0.55 \\
\hline $\begin{array}{l}\text { Neoplasms } \\
\text { (n) }\end{array}$ & 287 & $189 \cdot 42$ & 1.52 & 1.35 to 1.70 & $<0.0001$ \\
\hline Endocrine and metabolic disorders & 2 & $11 \cdot 38$ & $0 \cdot 18$ & 0.02 to 0.63 & 0.0054 \\
\hline Haematopoetic diseases & 3 & 1.97 & 1.52 & 0.31 to 4.45 & 0.45 \\
\hline Psychiatric diseases & 0 & $3 \cdot 14$ & 0.00 & 0.00 to 1.18 & 0.084 \\
\hline Diseases of the nervous system & 0 & $7 \cdot 14$ & 0.00 & 0.00 to 0.52 & $0 \cdot 0020$ \\
\hline \multicolumn{6}{|l|}{ Diseases of the heart and vascular } \\
\hline system & 454 & $497 \cdot 79$ & 0.91 & 0.83 to 1.00 & 0.044 \\
\hline Respiratory diseases & 108 & $69 \cdot 42$ & $1 \cdot 56$ & $1 \cdot 28$ to $1 \cdot 88$ & $<0.0001$ \\
\hline Gastrointestinal diseases & 36 & $29 \cdot 32$ & $1 \cdot 23$ & 0.87 to 1.71 & $0 \cdot 21$ \\
\hline \multicolumn{6}{|l|}{ Disorders of the kidneys and urinary } \\
\hline tract & 12 & 13.91 & $0 \cdot 86$ & 0.45 to 1.51 & 0.61 \\
\hline Diseases in male genital organs & 0 & $5 \cdot 54$ & 0.00 & 0.00 to 0.67 & $0 \cdot 0086$ \\
\hline Diseases in female genital organs & 0 & 0.03 & 0.00 & 0.00 to 113.49 & $1 \cdot 00$ \\
\hline Cutaneous diseases & 0 & $0 \cdot 31$ & 0.00 & 0.00 to 11.97 & $1 \cdot 00$ \\
\hline Diseases of bone and connective tissue & 0 & $2 \cdot 58$ & 0.00 & 0.00 to 1.43 & $0 \cdot 20$ \\
\hline Incomplete diagnosis & 4 & $9 \cdot 59$ & 0.42 & 0.11 to 1.07 & 0.074 \\
\hline \multicolumn{6}{|l|}{ Violent death and poisoning (suicide } \\
\hline excluded) & 26 & $27 \cdot 27$ & 0.95 & 0.59 to 1.32 & 0.91 \\
\hline Suicide & 42 & $14 \cdot 00$ & 3.00 & $2 \cdot 18$ to $4 \cdot 09$ & $<0.0001$ \\
\hline Postoperative death & 19 & - & - & - & - \\
\hline All deaths & 1001 & $896 \cdot 00$ & $1 \cdot 12$ & 1.05 to 1.19 & $0 \cdot 0005$ \\
\hline Postoperative deaths excluded & 982 & $896 \cdot 00$ & $1 \cdot 10$ & 1.03 to 1.17 & 0.0041 \\
\hline
\end{tabular}

$\mathrm{SMR}=$ standardised mortality ratio.

Swedish Health Care Region compiled by the central bureau of statistics (Statistics Sweden). Sweden is divided into six health care regions, of which the southern region accounts for $18 \%$ of the total population. Official data on Swedish death rates of specific causes are unreliable before 1951, and data for the Southern Health Care Region are at present available only from 1958. In the calculations we decided to include patients in the cohort who were alive on 1 January 1953, or who were operated on later, on the assumption that differences in death rates during the five year period, 1953-8, were negligible. One hundred and seventeen deaths (44 postoperative deaths included) and a total of 5455 person years $(15 \cdot 6 \%)$ were thus omitted. This procedure did not affect the sex ratio or the proportion of cases with different underlying ulcer disease, but the proportion of patients operated on with gastroenteroanastomosis decreased significantly.

The final calculations included 1323 patients (1104 males and 219 females) with an aggregate duration of a follow up of 29556 person years. In addition $71(5 \cdot 1 \%)$ more patients were operated on after 1953 who could not be traced because of inadequate addresses (28) or missing hospital records (43).
A Billroth I resection was performed in $\mathbf{1 7 9}$ cases $(13.5 \%$ ), and a Billroth III procedure in 1066 cases $(80.6 \%)$, and 78 patients $(5.9 \%)$ were operated on with a gastroenteroanastomosis. All main categories of the ICD were screened for. Malformations and diseases in early infancy, during pregnancy, and childbirth were omitted from the tables.

\section{Statistics}

Person years at risk and number of incident cases were calculated from the date of peptic ulcer surgery (or from 1 January 1953 for those operated on before that date) to death, emigration, or 31 December 1989, whichever occurred first. For gastric cancer, both expected and incident cases were calculated with a latency of five years after surgery to avoid patients who had a missed diagnosis of gastric carcinoma already at the time of surgery. Expected numbers of deaths for different causes were determined using age, sex, and calendar year specific death rates, and the standardised mortality ratio (SMR) was defined as the ratio between observed and expected numbers of deaths. To calculate significance values and confidence intervals (CI) of the SMR, it was assumed that observed numbers of deaths followed a Poisson distribution. All confidence intervals have 95\% confidence limits and all tests are two sided.

\section{Results}

Overall mortality in the cohort was higher than that in the general population, SMR $1 \cdot 12$ (CI 1.05 to $1 \cdot 19$ ), the differences remaining significant even after the exclusion of postoperative deaths SMR $1 \cdot 10$ (CI 1.03 to $1 \cdot 17$ ). The excess mortality was caused by malignant tumours, diseases of the respiratory organs, and suicide, and was to some extent offset by a decreased mortality in diseases in the circulatory organs, endocrine and metabolic diseases, and diseases in the nervous system and the male genital organs (Table I).

Excess deaths in malignant diseases resulted from neoplasias in the stomach; SMR 1.67 (CI $1 \cdot 22$ to $2 \cdot 27)$, pancreas; SMR 1.94 (CI $1 \cdot 25$ to $2 \cdot 95$ ), respiratory organs; SMR $2 \cdot 42$ (CI 1.89 to $3 \cdot 08)$ and male genital organs; SMR 1.45 (CI 1.04 to $2 \cdot 00$ ). The excess mortality in

TABLE II Mortality in the total cohort in some diagnostic groups and in some specific diagnoses by latency after operation

\begin{tabular}{|c|c|c|c|c|c|c|c|c|c|c|}
\hline \multirow[b]{2}{*}{ Diagnosis } & \multicolumn{5}{|c|}{ 0-19 Years postoperatively } & \multicolumn{5}{|c|}{$20+$ Years postoperatively } \\
\hline & Obs & $\operatorname{Exp}$ & $S M R$ & $\begin{array}{l}\text { Confidence } \\
\text { interval }\end{array}$ & $\stackrel{p}{\text { Value }}$ & Obs & $\operatorname{Exp}$ & $S M R$ & $\begin{array}{l}\text { Confidence } \\
\text { interval }\end{array}$ & $\stackrel{P}{\text { Value }}$ \\
\hline $\begin{array}{l}\text { Malignant tumours } \\
\text { Disease in respiratory organs } \\
\text { Disease in circulatory organs } \\
\text { Gastric carcinoma } \\
\text { Pancreatic carcinoma } \\
\text { Carcinoma in large bowel (rectum excluded) } \\
\text { Unspecified abdominal tumour location } \\
\text { Carcinoma in respiratory organs } \\
\text { Ischaemic heart disease } \\
\text { Suicide }\end{array}$ & $\begin{array}{r}89 \\
38 \\
183 \\
7 \\
2 \\
4 \\
3 \\
30 \\
199 \\
26\end{array}$ & $\begin{array}{r}78 \cdot 15 \\
24 \cdot 47 \\
192 \cdot 63 \\
13 \cdot 8 \\
5 \cdot 08 \\
6 \cdot 84 \\
0 \cdot 26 \\
10 \cdot 69 \\
115 \cdot 66 \\
8 \cdot 91\end{array}$ & $\begin{array}{r}1.14 \\
1.55 \\
0.95 \\
0.53 \\
0.39 \\
0.59 \\
11.58 \\
2.81 \\
1.03 \\
2.92\end{array}$ & $\begin{array}{l}0.92 \text { to } 1.41 \\
1.11 \text { to } 2 \cdot 15 \\
0.82 \text { to } 1.10 \\
0.21 \text { to } 1.09 \\
0.05 \text { to } 1.42 \\
0.16 \text { to } 1.50 \\
2.39 \text { to } 33.85 \\
1.92 \text { to } 4.05 \\
0.85 \text { to } 1.23 \\
1.93 \text { to } 4.33\end{array}$ & $\begin{array}{l}0 \cdot 21 \\
0 \cdot 0062 \\
0 \cdot 49 \\
0 \cdot 082 \\
0 \cdot 26 \\
0.44 \\
0.0024 \\
<0.001 \\
0 \cdot 76 \\
<0.001\end{array}$ & $\begin{array}{r}198 \\
70 \\
271 \\
36 \\
21 \\
18 \\
7 \\
39 \\
174 \\
16\end{array}$ & $\begin{array}{r}109 \cdot 44 \\
44 \cdot 94 \\
305 \cdot 10 \\
12 \cdot 5 \\
6 \cdot 78 \\
10 \cdot 19 \\
0 \cdot 43 \\
17 \cdot 82 \\
197 \cdot 44 \\
5 \cdot 09\end{array}$ & $\begin{array}{r}1 \cdot 81 \\
1 \cdot 56 \\
0 \cdot 89 \\
2 \cdot 88 \\
3 \cdot 10 \\
1 \cdot 77 \\
16 \cdot 15 \\
2 \cdot 19 \\
0 \cdot 88 \\
3 \cdot 14\end{array}$ & $\begin{array}{l}1 \cdot 57 \text { to } 2 \cdot 08 \\
1 \cdot 22 \text { to } 1.98 \\
0.79 \text { to } 1 \cdot 00 \\
2 \cdot 04 \text { to } 4 \cdot 02 \\
1.95 \text { to } 4 \cdot 80 \\
1 \cdot 07 \text { to } 2 \cdot 84 \\
6.49 \text { to } 33 \cdot 28 \\
1 \cdot 57 \text { to } 3 \cdot 01 \\
0.76 \text { to } 1 \cdot 02 \\
1 \cdot 84 \text { to } 5 \cdot 19\end{array}$ & $\begin{array}{c}<0.0001 \\
0.0002 \\
0.045 \\
<0.0001 \\
<0.0001 \\
0.014 \\
<0.0001 \\
<0.0001 \\
0.089 \\
0.0001\end{array}$ \\
\hline Total mortality & 399 & $365 \cdot 38$ & 1.09 & 0.99 to 1.21 & 0.072 & 602 & 530.55 & $1 \cdot 13$ & 1.05 to 1.23 & 0.0019 \\
\hline
\end{tabular}

Obs $=$ observed number of deaths, Exp=expected number of deaths, $S M R=$ standardised mortality ratio, confidence interval=95\% confidence interval (two sided $p$ values). 


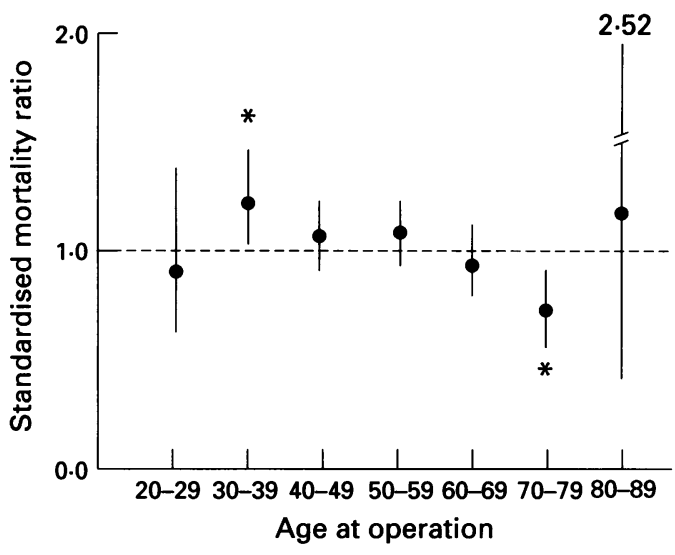

The impact of age at surgery on overall mortality expressed as the SMR for all causes of death in 10 year intervals (postoperative deaths excluded). ${ }^{\star} p<0.05$.

cancer in the respiratory organs was found during the whole postoperative period, whereas mortality in gastrointestinal malignancies was increased only from 20 years and onwards postoperatively (Table II). Mortality in gastrointestinal malignancies outnumbered deaths from neoplasias in the respiratory organs.

The impact of age at surgery on mortality, postoperative deaths excluded, was investigated by calculating the SMR for all causes of deaths in 10 year intervals (Figure). It was high among patients operated on between the ages of 30 and 59 years, but slightly decreased among those operated upon between 70 and 79 years of age.

The group operated on before the age of 45 years had a $31 \%$ increase in overall mortality (Table III). During the first 19 years after surgery, a $60 \%$ excess mortality was found, which was caused by cardiovascular disease, respiratory diseases, and suicide. From 20 years postoperatively and onwards, an increased death rate in neoplasms was added to the other causes of excess deaths, except for cardiovascular diseases, which was decreased by $18 \%$, although the difference was not statistically significant. Gastric cancer mortality was slightly increased during the first postoperative period, but was four times the expected from 20 years and onwards (Table IV). For pancreatic cancer, the pattern was almost identical with a more than fourfold increase in mortality during the latter period (Table IV). Mortality because of oesophageal carcinoma was increased throughout the whole postoperative period in this group. Among ulcer patients operated on at or over the age of 45 years, overall mortality was almost comparable to that in the general population during the first 20 years after operation but slightly higher thereafter (Table V). Death rates in respiratory diseases were increased by about $50 \%$, and the suicide rate was about 2.5 times higher throughout the follow up period. A decreased risk of dying from cardiovascular diseases, endocrine and metabolic disorders, diseases in male genital organs or in the nervous system was found throughout the postoperative period. As gastric cancer mortality was considerably decreased during the first postoperative period, but significantly increased during the latter period, overall mortality in gastric cancer was almost comparable to that in the reference population (Table VI). Pancreatic cancer mortality was increased more than 20 years postoperatively (Table VI).

Mortality caused by malignancy in the brain and nervous system (SMR 3.78 (CI 1.63 to $7 \cdot 46)$ ) and male genital organs (SMR 1.45 (CI 0.99 to 2.09 )) was increased only among those operated on after the age of 44 regardless of time elapsed since surgery.

\section{Discussion}

Total mortality in the whole cohort of ulcer patients operated on with partial gastric resection was found to be higher than in the general population, a finding in agreement with some studies ${ }^{1} 2131419$ but in contrast with others. ${ }^{5}$ These discrepancies may result from differences in the selection of patients or reference populations, or both, regional differences, or differences in follow up. Moreover, it may be difficult to make comparisons

TABLE III Mortality in persons operated on before the age of 45 years, by diagnostic categories and by time elapsed since operation. Postoperative deaths $(n=1)$ excluded

\begin{tabular}{|c|c|c|c|c|c|c|c|c|c|}
\hline \multirow[t]{3}{*}{$\begin{array}{l}\text { Subjects }(n) \\
\text { Person years }\end{array}$} & \multicolumn{3}{|c|}{$\begin{array}{l}483 \\
7600\end{array}$} & \multicolumn{3}{|c|}{$\begin{array}{l}448 \\
6825\end{array}$} & \multicolumn{3}{|c|}{$\begin{array}{l}509 \\
14426\end{array}$} \\
\hline & \multicolumn{3}{|c|}{$0-19$ Years } & \multicolumn{3}{|c|}{$20+$ Years } & \multicolumn{3}{|l|}{ Total } \\
\hline & Obs & $\operatorname{Exp}$ & $S M R$ & Obs & $\operatorname{Exp}$ & $S M R$ & Obs & $\operatorname{Exp}$ & $S M R$ \\
\hline $\begin{array}{l}\text { Infectious diseases } \\
\text { Neoplasms } \\
\text { Endocrine and metabolic disorders } \\
\text { Haematopoietic diseases } \\
\text { Psychiatric diseases } \\
\text { Diseases of the nervous system } \\
\text { Diseases of the heart and vascular system } \\
\text { Respiratory diseases } \\
\text { Gastrointestinal diseases } \\
\text { Disorders of the kidneys and urinary tract } \\
\text { Diseases in male genital organs } \\
\text { Diseases in female genital organs } \\
\text { Cutaneous diseases } \\
\text { Diseases of bone and connective tissue } \\
\text { Incomplete diagnosis } \\
\text { Violent death (suicide excluded) } \\
\text { Suicide }\end{array}$ & $\begin{array}{r}0 \\
11 \\
0 \\
0 \\
0 \\
0 \\
22 \\
4 \\
2 \\
1 \\
0 \\
0 \\
0 \\
0 \\
0 \\
5\end{array}$ & $\begin{array}{r}0 \cdot 56 \\
9 \cdot 20 \\
0 \cdot 47 \\
0 \cdot 09 \\
0 \cdot 15 \\
0.53 \\
12 \cdot 55 \\
1.33 \\
1.53 \\
0 \cdot 75 \\
0 \cdot 03 \\
0 \cdot 00 \\
0 \cdot 02 \\
0 \cdot 12 \\
0 \cdot 17 \\
3 \cdot 55 \\
3 \cdot 28\end{array}$ & $\begin{array}{l}0.00 \\
1.20 \\
0 \cdot 00 \\
0 \cdot 00 \\
0 \cdot 00 \\
0 \cdot 00 \\
1.75^{\star} \\
3 \cdot 01^{\star} \\
1.31 \\
1.33 \\
0 \cdot 00 \\
0 \cdot 00 \\
0 \cdot 00 \\
0 \cdot 00 \\
0.00 \\
1.44 \\
3 \cdot 36^{\star \star \star}\end{array}$ & $\begin{array}{r}2 \\
84 \\
0 \\
1 \\
0 \\
0 \\
77 \\
21 \\
8 \\
0 \\
0 \\
0 \\
0 \\
0 \\
0 \\
10 \\
12\end{array}$ & $\begin{array}{r}1.04 \\
43.45 \\
2.21 \\
0.31 \\
0.72 \\
1.63 \\
93.43 \\
11.72 \\
5.24 \\
2.10 \\
0.43 \\
0.00 \\
0.06 \\
0.59 \\
0.66 \\
5.42 \\
3.03\end{array}$ & $\begin{array}{l}1.91 \\
1.93^{\star \star \star} \\
0.00 \\
3.21 \\
0.00 \\
0.00 \\
0.82 \\
1.79^{\star \star} \\
1.53 \\
0.00 \\
0.00 \\
0.00 \\
0.00 \\
0.00 \\
0.00 \\
1.85 \\
3.96^{\star \star \star}\end{array}$ & $\begin{array}{r}2 \\
95 \\
0 \\
1 \\
0 \\
1 \\
99 \\
25 \\
10 \\
1 \\
0 \\
0 \\
0 \\
0 \\
0 \\
15 \\
23\end{array}$ & $\begin{array}{r}1.61 \\
52.66 \\
2.68 \\
0.40 \\
0.87 \\
2.15 \\
105.98 \\
13.05 \\
6.77 \\
2.85 \\
0.47 \\
0.01 \\
0.08 \\
0.72 \\
0.83 \\
8.97 \\
6.31\end{array}$ & 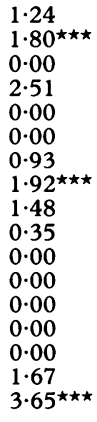 \\
\hline All deaths & 56 & $35 \cdot 10$ & $1 \cdot 60^{\star \star}$ & 215 & $172 \cdot 45$ & $1 \cdot 25^{\star \star}$ & 271 & 207.55 & $1 \cdot 31^{\star \star \star}$ \\
\hline
\end{tabular}

$\star=\mathrm{p}<0.05,{ }^{\star \star}=\mathrm{p}<0.01,{ }^{\star \star \star}=\mathrm{p}<0.001$ (two sided $\mathrm{p}$ values). Abbreviations as in Table II. 
TABLE IV Mortality in gastrointestinal carcinoma in persons operated on before the age of 45 years, by time elapsed since operation.

\begin{tabular}{|c|c|c|c|c|c|c|c|c|c|}
\hline \multirow[t]{3}{*}{$\begin{array}{l}\text { Subjects (n) } \\
\text { Person years }\end{array}$} & \multicolumn{3}{|c|}{$\begin{array}{l}483 \\
7600\end{array}$} & \multicolumn{3}{|c|}{$\begin{array}{l}448 \\
6825\end{array}$} & \multicolumn{3}{|c|}{$\begin{array}{l}509 \\
14426\end{array}$} \\
\hline & \multicolumn{3}{|c|}{$0-19$ Years } & \multicolumn{3}{|c|}{$20+$ Years } & \multicolumn{3}{|c|}{ Total } \\
\hline & Obs & $\operatorname{Exp}$ & $S M R$ & Obs & $\operatorname{Exp}$ & $S M R$ & Obs & $\operatorname{Exp}$ & $S M R$ \\
\hline $\begin{array}{l}\text { Oesophagus } \\
\text { Stomach } \dagger \\
\text { Small bowel } \\
\text { Colon } \\
\text { Rectum } \\
\text { Liver and intrahepatic biliary tract } \\
\text { Gall bladder and extrahepatic biliary tract } \\
\text { Pancreas } \\
\text { Peritoneum } \\
\text { Unspecified tumour location }\end{array}$ & $\begin{array}{l}2 \\
3 \\
0 \\
1 \\
0 \\
0 \\
0 \\
0 \\
0 \\
0\end{array}$ & $\begin{array}{l}0 \cdot 16 \\
1.06 \\
0.03 \\
0 \cdot 65 \\
0.53 \\
0 \cdot 10 \\
0 \cdot 13 \\
0 \cdot 58 \\
0 \cdot 07 \\
0 \cdot 01\end{array}$ & $\begin{array}{c}12 \cdot 15^{\star} \\
2 \cdot 84 \\
0 \cdot 00 \\
1 \cdot 53 \\
0 \cdot 00 \\
0 \cdot 00 \\
0 \cdot 00 \\
0 \cdot 00 \\
0 \cdot 00 \\
0.00\end{array}$ & $\begin{array}{r}2 \\
18 \\
0 \\
7 \\
2 \\
2 \\
2 \\
12 \\
1 \\
2\end{array}$ & $\begin{array}{l}0.95 \\
4 \cdot 43 \\
0 \cdot 11 \\
3 \cdot 58 \\
2 \cdot 21 \\
0.95 \\
0 \cdot 85 \\
2 \cdot 85 \\
0 \cdot 16 \\
0 \cdot 10\end{array}$ & $\begin{array}{l}2 \cdot 11 \\
4 \cdot 06^{\star \star \star} \\
0 \cdot 00 \\
1 \cdot 96 \\
0 \cdot 90 \\
2 \cdot 10 \\
2 \cdot 37 \\
4 \cdot 20^{\star \star \star} \\
6 \cdot 36 \\
20 \cdot 08^{\star \star}\end{array}$ & $\begin{array}{r}4 \\
21 \\
0 \\
8 \\
2 \\
2 \\
2 \\
12 \\
1 \\
2\end{array}$ & $\begin{array}{l}1 \cdot 11 \\
5 \cdot 49 \\
0 \cdot 14 \\
4 \cdot 23 \\
2 \cdot 74 \\
1 \cdot 06 \\
0 \cdot 97 \\
3 \cdot 44 \\
0 \cdot 22 \\
0 \cdot 11\end{array}$ & $\begin{array}{l}3.59^{\star} \\
3.83^{\star \star \star} \\
0.00 \\
1.89 \\
0.73 \\
1.89 \\
2.06 \\
3.49^{\star \star \star} \\
4.63 \\
18.00^{\star \star}\end{array}$ \\
\hline All deaths & 6 & 3.37 & $1 \cdot 78$ & 48 & $15 \cdot 98$ & $3 \cdot 00^{\star \star \star}$ & 54 & $19 \cdot 35$ & $2 \cdot 79^{\star \star \star}$ \\
\hline
\end{tabular}

${ }^{\star}=\mathrm{p}<0.05,{ }^{\star \star}=\mathrm{p}<0.01,{ }^{\star \star \star}=\mathrm{p}<0.001$ (two sided $\mathrm{p}$ values). + With five years latency time. Abbreviations as in Table II.

between contemporary findings and those obtained in studies covering time spans in the earlier part of the century (for example, Krause 1958), when preconditions and criteria may have differed. Our cohort has been followed up for 29 to 59 years, and $78 \%$ of the traced study population have died, suggesting the results to have strong validity also in advanced age groups.

We found the overall risk of dying of cardiovascular diseases to be decreased, a finding in line with some previous studies ${ }^{517}$ but in contrast with others. ${ }^{13-15}$ A lower risk of coronary heart diseases during the first postoperative period is to be expected, because of the selection of those fit for surgery. In this study, however, patients operated on before the age of 45 years had a $75 \%$ increase in death rate in cardiovascular disease during the first 19 years after operation, decreasing to a $18 \%$ lower SMR during the latter study period, whereas among those operated on at or over the age of 45 years cardiovascular disease mortality seemed lower in both periods. Doll and Peto found the correlation between smoking and ischaemic heart disease to be strong in young people, and to weaken with increasing age 20 and coronary sclerosis, which has been found to be especially severe in young and middle aged men with peptic ulcer, ${ }^{21}$ is probably less manifest in the preoperative selection phase among young patients.

The finding of a longterm lower mortality in cardiovascular disease might suggest the possibility of some protective effect of the operation. Fat malabsorption is a common finding after partial resection ${ }^{22} 23$ resulting in lower concentrations of serum triglycerides and cholesterol. ${ }^{1724}$ Dietary intervention trials have shown reduction of serum lipids to arrest coronary lesion growth, ${ }^{25}$ and significantly reduce mortality in ischaemic heart disease. ${ }^{26}$ Other factors that might decrease cardiovascular disease mortality are low packed red cell volumes ${ }^{27}$ often associated with partial gastric resection, 1217 and low blood pressure. ${ }^{17} 28$ In three studies where operated and non-operated ulcer patients were compared with the general population, excess mortality was found in both morbid groups during the first few years after diagnosis only, subsequent mortality being comparable to that in the general popula-tion. ${ }^{1829} 30$ Mortality in cardiovascular disease was found to be decreased both among medically treated and among surgically treated ulcer patients, ${ }^{29}$ while among operated ulcer patients both a tendency towards a lower mortality ${ }^{13} 17$ and a higher

TABLE V Mortality in persons operated on at or after the age of 45 years by diagnostic categories and by time elapsed since operation. Postoperative deaths $(n=18)$ excluded

\begin{tabular}{|c|c|c|c|c|c|c|c|c|c|}
\hline \multirow[t]{3}{*}{$\begin{array}{l}\text { Subjects (n) } \\
\text { Person years }\end{array}$} & \multicolumn{3}{|c|}{$\begin{array}{l}771 \\
10906\end{array}$} & \multicolumn{3}{|c|}{$\begin{array}{l}470 \\
4223\end{array}$} & \multicolumn{3}{|c|}{$\begin{array}{l}795 \\
15129\end{array}$} \\
\hline & \multicolumn{3}{|c|}{$0-19$ Years } & \multicolumn{3}{|c|}{$20+$ Years } & \multicolumn{3}{|c|}{ Total } \\
\hline & Obs & $\operatorname{Exp}$ & $S M R$ & Obs & $\operatorname{Exp}$ & $S M R$ & Obs & $\operatorname{Exp}$ & $S M R$ \\
\hline Infectious diseases & 4 & $2 \cdot 74$ & 1.46 & 2 & $2 \cdot 07$ & 0.97 & 6 & $4 \cdot 82$ & $1 \cdot 25$ \\
\hline Neoplasms & 78 & $70 \cdot 76$ & $1 \cdot 10$ & 114 & 65.99 & $1 \cdot 73^{\star \star \star}$ & 192 & $136 \cdot 76$ & $1.40^{\star \star \star}$ \\
\hline Endocrine and metabolic disorders & 1 & 3.96 & 0.25 & 1 & $4 \cdot 74$ & 0.21 & 2 & $8 \cdot 70$ & $0.23^{\star}$ \\
\hline Haematopoietic diseases & 0 & 0.79 & 0.00 & 2 & $0 \cdot 78$ & $2 \cdot 57$ & 2 & 1.57 & $1 \cdot 27$ \\
\hline Psychiatric diseases & 0 & 0.82 & 0.00 & 0 & 1.45 & 0.00 & 0 & $2 \cdot 27$ & $0 \cdot 00$ \\
\hline Diseases of the nervous system & 0 & $2 \cdot 48$ & $0 \cdot 00$ & 0 & $2 \cdot 51$ & $0 \cdot 00$ & 0 & 4.99 & $0 \cdot 00^{\star \star}$ \\
\hline Diseases of the heart and vascular system & 161 & $180 \cdot 08$ & $0 \cdot 89$ & 194 & $211 \cdot 67$ & 0.92 & 355 & $391 \cdot 80$ & 0.91 \\
\hline Respiratory diseases & 34 & $23 \cdot 14$ & $1 \cdot 47^{\star}$ & 49 & $33 \cdot 23$ & $1 \cdot 47^{\star \star}$ & 83 & $56 \cdot 37$ & $1 \cdot 47^{\star \star \star}$ \\
\hline Gastrointestinal diseases & 19 & $11 \cdot 45$ & $1 \cdot 66^{\star}$ & 7 & $11 \cdot 09$ & 0.63 & 26 & $22 \cdot 54$ & $1 \cdot 15$ \\
\hline Disorders of the kidneys and urinary tract & 6 & $5 \cdot 33$ & $1 \cdot 12$ & 5 & $5 \cdot 72$ & 0.87 & 11 & $11 \cdot 06$ & 0.99 \\
\hline Diseases in male genital organs & 0 & $2 \cdot 76$ & 0.00 & 0 & $2 \cdot 31$ & 0.00 & 0 & $5 \cdot 07$ & $0.00^{\star}$ \\
\hline Diseases in female genital organs & 0 & 0.02 & 0.00 & 0 & 0.01 & 0.00 & 0 & 0.03 & 0.00 \\
\hline Cutaneous diseases & 0 & 0.09 & $0 \cdot 00$ & 0 & $0 \cdot 14$ & 0.00 & 0 & $0 \cdot 23$ & 0.00 \\
\hline Diseases of bone and connective tissue & 0 & 0.93 & 0.00 & 0 & 0.94 & 0.00 & 0 & 1.86 & 0.00 \\
\hline Incomplete diagnosis & 0 & 4.51 & $0 \cdot 00^{\star}$ & 4 & $4 \cdot 25$ & 0.94 & 4 & $8 \cdot 76$ & 0.46 \\
\hline Violent death (suicide excluded) & 6 & 9.94 & 0.60 & 5 & $8 \cdot 36$ & $0 \cdot 60$ & 11 & $18 \cdot 30$ & $0 \cdot 60$ \\
\hline Suicide & 15 & $5 \cdot 63$ & $2 \cdot 67^{\star \star \star}$ & 4 & $2 \cdot 06$ & 1.94 & 19 & $7 \cdot 69$ & $2 \cdot 47^{\star \star \star}$ \\
\hline All deaths & 324 & $330 \cdot 28$ & 0.98 & 387 & $358 \cdot 10$ & 1.08 & 711 & $688 \cdot 44$ & 1.03 \\
\hline
\end{tabular}

$\star=\mathrm{p}<0.05,{ }^{\star \star}=\mathrm{p}<0.01, \star \star \star=\mathrm{p}<0.001$ (two sided $\mathrm{p}$ values). Abbreviations as in Table II. 
TABLE VI Mortality in gastrointestinal carcinoma in persons operated on at or after the age of 45 years, by time elapsed since operation.

\begin{tabular}{|c|c|c|c|c|c|c|c|c|c|}
\hline \multirow[t]{3}{*}{$\begin{array}{l}\text { Subjects }(n) \\
\text { Person years }\end{array}$} & \multicolumn{3}{|c|}{$\begin{array}{l}771 \\
10906\end{array}$} & \multicolumn{3}{|c|}{$\begin{array}{l}470 \\
4223\end{array}$} & \multicolumn{3}{|c|}{$\begin{array}{l}795 \\
15130\end{array}$} \\
\hline & \multicolumn{3}{|c|}{$0-19$ Years } & \multicolumn{3}{|c|}{$20+$ Years } & \multicolumn{3}{|c|}{ Total } \\
\hline & Obs & $\operatorname{Exp}$ & $S M R$ & Obs & $\operatorname{Exp}$ & $S M R$ & $O b s$ & $\operatorname{Exp}$ & $S M R$ \\
\hline $\begin{array}{l}\text { Oesophagus } \\
\text { Stomach }{ }^{-} \\
\text {Small bowel } \\
\text { Colon } \\
\text { Rectum } \\
\text { Liver and intrahepatic biliary tract } \\
\text { Gall bladder and extrahepatic biliary tract } \\
\text { Pancreas } \\
\text { Peritoneum } \\
\text { Unspecified tumour location }\end{array}$ & $\begin{array}{l}1 \\
4 \\
0 \\
3 \\
2 \\
0 \\
1 \\
2 \\
0 \\
0\end{array}$ & $\begin{array}{r}1 \cdot 43 \\
10 \cdot 11 \\
0 \cdot 16 \\
6 \cdot 19 \\
4 \cdot 24 \\
0 \cdot 91 \\
1 \cdot 29 \\
4 \cdot 50 \\
0 \cdot 31 \\
0 \cdot 25\end{array}$ & $\begin{array}{l}0 \cdot 70 \\
0 \cdot 40^{\star} \\
0 \cdot 00 \\
0 \cdot 48 \\
0 \cdot 47 \\
0 \cdot 00 \\
0 \cdot 78 \\
0 \cdot 44 \\
0 \cdot 00 \\
12 \cdot 12^{\star \star}\end{array}$ & $\begin{array}{r}1 \\
18 \\
0 \\
11 \\
3 \\
2 \\
0 \\
9 \\
0 \\
5\end{array}$ & $\begin{array}{l}1 \cdot 15 \\
8 \cdot 07 \\
0 \cdot 13 \\
6 \cdot 61 \\
3 \cdot 58 \\
1 \cdot 32 \\
1 \cdot 31 \\
3 \cdot 93 \\
0 \cdot 20 \\
0 \cdot 33\end{array}$ & $\begin{array}{l}0 \cdot 87 \\
2 \cdot 23^{\star \star} \\
0 \cdot 00 \\
1 \cdot 66 \\
0 \cdot 84 \\
1 \cdot 51 \\
0 \cdot 00 \\
2 \cdot 29^{\star} \\
0 \cdot 00 \\
14 \cdot 98^{\star \star \star}\end{array}$ & $\begin{array}{r}2 \\
22 \\
0 \\
14 \\
5 \\
2 \\
1 \\
11 \\
0 \\
8\end{array}$ & $\begin{array}{r}2 \cdot 58 \\
18 \cdot 18 \\
0 \cdot 30 \\
12 \cdot 79 \\
7 \cdot 82 \\
2 \cdot 23 \\
2 \cdot 60 \\
8 \cdot 42 \\
0 \cdot 52 \\
0 \cdot 58\end{array}$ & $\begin{array}{c}0.78 \\
1.21 \\
0.00 \\
1.09 \\
0.64 \\
0.90 \\
0.39 \\
1.31 \\
0.00 \\
13.76^{\star \star \star}\end{array}$ \\
\hline All deaths & 16 & $31 \cdot 27$ & $0.51^{\star \star}$ & 49 & $26 \cdot 52$ & $1 \cdot 85^{\star \star \star}$ & 65 & $57 \cdot 80$ & $1 \cdot 12$ \\
\hline
\end{tabular}

$\star=\mathrm{p}<0.05,{ }^{\star \star}=\mathrm{p}<0.01,{ }^{\star \star \star}=\mathrm{p}<0.001$ (two sided $\mathrm{p}$ values). +With five years latency time. Abbreviations as in Table II.

mortality in cardiovascular disease ${ }^{18}$ have been found. Asano et al found the SMR for cardiovascular disease to be increased only among postgastrectomy patients who were smokers, that among non-smokers being significantly decreased. ${ }^{15}$

An excess mortality in suicide has been a common finding after ulcer surgery, ${ }^{1} 251114$ but it is probably related to the ulcer disease and not surgery in itself. This interpretation has support from a report by Viskum who studied 2619 ulcer patients after attempted or committed suicide and found no difference between the operated and non-operated subgroups. ${ }^{31}$

In this study, the risk of dying of endocrine and metabolic disorders, or diseases in male genital organs or the nervous system was found to be decreased, especially in the older age group, probably because of the selection criteria for surgery.

Most operated ulcer patients are smokers, ${ }^{1314161728}$ and consequently the finding of an excess risk of dying of benign or malignant respiratory disease is to be expected, although we cannot account for the smoking status in this study.

Our findings confirm previous reports of an increased mortality in gastric carcinoma, ${ }^{11932} 33$ which was found in the total cohort regardless of age at surgery but with a latency of more than 20 years postoperatively indicating it to be directly related to surgery. Those operated on after 44 years of age had only one third of the expected mortality in gastric cancer during the first 19 years after surgery, though the death rate was more than doubled in the latter period. The younger age group at surgery had four times the expected mortality in this disease with a 20 year lag period. Gastric cancer is considered to be a rare finding in non-operated duodenal ulcer patients. ${ }^{34}{ }^{35}$ In a study of 13000 necropsies performed in a single hospital over 20 years, together with a series of 7000 necropsies performed at 17 hospitals during one year, Hole and coworkers found a significantly lower frequency of gastric cancer in persons with pathological evidence of either chronic gastric or duodenal ulcer. ${ }^{36}$

Whether the increased mortality in pancreatic carcinoma, also found by others ${ }^{7} 1437$ is the result of the operation, smoking or other causes is not known. It followed the same pattern as that of gastric carcinoma - that is, a decreased mortality during the first 19 postoperative years replaced by a quadrupled death rate during the following years among those of young age at surgery - though mortality was also increased among the older patients after this lag period. Similar trends in pancreatic cancer incidence have been reported previously, ${ }^{712}$ and point to the existence of some relation to surgery. ${ }^{738}$

In this study, excess deaths resulting from gastrointestinal malignancies outnumbered the increased number of deaths caused by carcinomas in the respiratory organs, a finding in contrast with those of others. ${ }^{13} 14$ This discrepancy is probably the result of the longer follow up in this study. The rate of malignancies in respiratory organs was unaffected by time elapsed since surgery, whereas the frequency of gastrointestinal malignancies rose considerably from 20 years and onwards.

An increased death rate resulting from tumours in the nervous system was found among those operated on at an older age. Recently both higher ${ }^{12}$ and lower ${ }^{5}$ incidences of nervous system malignancies, compared with the general population, have been reported. We have no hypothesis as to the cause of the increased mortality found in our study.

Deriving causes of death from death certificates is a somewhat unreliable method ${ }^{39}$ that tends to underestimate the true frequency of, for example, gastric carcinoma. ${ }^{40}$ Diagnoses of neoplasms as well as of cardiovascular diseases are known, however, to be burdened with the least error, ${ }^{39}$ and other feasible methods of comparing cause of death in a retrospective study group to corresponding data for the general population are not available, and the same problems of inaccuracy probably exist in both groups. ${ }^{41}$ In this study, all the death certificates of the cohort were classified by one of the team (SE) using the criteria of the ICD 8, whereas the reference rates were based on official statistics. This may constitute a source of error, as interpretation of the raw data might have changed over the years at the central bureau of statistics (Statistics Sweden), and a clinician's judgment may be influenced by a variety of factors. However, as 
the calculations, except for gastrointestinal malignancies and suicide, are based on the SMR for the main ICD 8 categories, this source of error is probably negligible, and differences would not affect comparisons regarding the impact of age at surgery.

We have been unable to include all deaths in the cohort in our calculations, as valid death rates in the reference population are lacking for the two decades during which the patients were operated on. The 73 deaths thus omitted, however, constitute only $7 \%$ of all deaths, and the effect on power of the study is marginal.

Ulcer patients coming to surgery are subjected to a dual selection procedure that might affect mortality in various ways. On the one hand, it can be assumed that these patients have a more advanced ulcer disease coupled with excess smoking ${ }^{17}$ and different pattern of social behaviour, ${ }^{15} 42$ but on the other hand it is likely that the preoperative investigation results in the rejection of patients at increased operative risk, especially among those in the older age group. This makes it difficult to draw conclusions on mortality among all those operated on, and thus analyses of subgroups of surgically treated ulcer patients are important. We have evaluated mortality and the impact of age at surgery, and found patients operated on before the age of 45 to constitute a high risk group with increased mortality regardless of time elapsed since surgery. Excess deaths resulting from gastrointestinal malignancies, mainly gastric and pancreatic carcinoma, outnumbered the increased number of death caused by cancer in the respiratory organs.

We are indebted to Torgil Möller, $\mathrm{MD}, \mathrm{PhD}$, and Bo Midberg, system coordinator, at the Southern Swedish Regional Tumour system coordinator, at the Southern Swedish Regional Tumour supported by grants from the Medical Faculty, Lund University, Lund, Sweden.

1 Krause U. Late prognosis after gastrectomy for ulcer. Acto Chir Scand 1958; 114: 341-54.

2 Fischer A. Twenty five years after Billroth II gastrectomy for duodenal ulcer. World 7 Surg 1984; 8: 293-302.

3 Eriksson S. The operated stomach. Bulletin no 36 from the Department of Surgery. Sweden: University of Lund, 1983.

4 Tokudome S, Kono S, Ikeda M, Kuratsune M, Sano C, Inokuchi $\mathrm{K}$, et al. A prospective study on primary gasInokuchi $\mathrm{K}$, et al. A prospective study on primary gastric stump cancer following partial gastrectomy for benign gast

5 Lundegårdh G. Mortality and cancer incidence following partial gastrectomy for benign ulcer diseases. Acta Universitatis Upsaliensis, Comprehensive summaries of Uppsala Dissertations. Uppsala, Sweden: University of Uppsala, Faculty of Medicine 289, 1991.

6 Viste A, Björnestad E, Opheim P, Skarstein E, Thunold J, Hartveit F, et al. Risk of carcinoma following gastric operations for benign disease: a historical cohort study of 3470 patients. Lancet 1986; ii: $502-5$.

7 Caygill C, Hill M, Kirkham J, Northfield T. Increased risk of cancer at multiple sites following gastric surgery for peptic ulcer. Gut 1987; 28: 924-8.

8 Lundegårdh G, Adami HO, Helmick C, Zack M, Meirik O. Stomach cancer following partial gastrectomy for benign ulcer disease. N Engl $\mathcal{F}$ Med 1988; 319: 195-200.

9 Offerhaus G, Tersmette A, Huibregtse $K$, van de Stadt J, Tersmette K, Stijnen T, et al. Mortality caused by stomach cancer after remote partial gastrectomy for benign conditions: 40 years of follow up of an Amsterdam cohort of 2633 postgastrectomy patients. Gut 1988; 29: 1588-90. 10 Toftgaard C. Gastric cancer after peptic ulcer surgery. A
historic prospective cohort investigation. Ann Surg 1989; 210: $159-64$
11 Inokuchi $\mathrm{K}$, Tokudome S, Ikeda M, Kuratsune M, Ichimiya H, Kaibara N, et al. Mortality from carcinoma after partial gastrectomy. Gann 1984; 75: 588-94.

12 Möller $\mathrm{H}$, Toftgaard C. Cancer occurrence in a cohort of patients surgically treated for peptic ulcer. Gut 1991; 32: $740-4$.

13 Macintyre I, O'Brien F. Death from malignant disease after surgery for duodenal ulcer. Gut 1994; 35: 451-4.

14 McLean Ross H, Smith M, Andersson J, Small W. Late mortality after surgery for peptic ulcer. $N$ Engl $\mathcal{f}$ Med 1982; 307: 519-22.

15 Din N, Small W. Death after partial gastrectomy - a long term study [Abstract]. Gut 1974; 15: 335.

16 Asano A, Mizuno S, Sasaki R, Aoki K, Yokoyama $H$, Yokoyama $Y$. The long term prognosis of patients gastrectomised for benign gastroduodenal diseases. $Y_{p n} \mathcal{f}$ Cancer Res 1987; 78: 337-48.

7 Stemmermann G, Heilbrun L, Nomura A, Rhoads G, Glober $\mathrm{G}$. Late mortality after partial gastrectomy. Int $\mathcal{f}$ Epidemiol 1984; 13: 299-303.

18 Westlund K. Mortality of peptic ulcer patients. Acta Med Scand 1963; 174 (suppl 402): 1-73.

19 Cheli R, Molinari F, Sani L, Ciancamerla G, Puntoni R. Gastric stump cancer: statistical evaluation. Rendic Gastroenterol 1977; 9: 169-72.

20 Doll R, Peto R. Mortality in relation to smoking: 20 years observations on male British doctors. BMf 1976; 2: $1525-36$

21 Watkinson G. Relation of chronic peptic ulcer to coronary sclerosis. Gastroenterologia 1958; 89: 292-301.

22 Lawrence W, Vanamee P, Peterson A, McNeer G, Levin S, Randall $\mathrm{H}$. Alterations in fat and nitrogen balance after total and subtotal gastrectomy. Surg Gynecol Obstet 1960; 11: 601-16.

23 Small W. The long term results of peptic ulcer surgery. Clin Gastroenterol 1973; 2: 427-45.

24 Glober G, Rhoads G, Lin F, Kagan A. The effects of partial gastrectomy on lipoproteins and other characteristics.

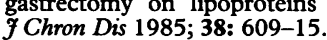

25 Arntzenius A, Kromhout D, Barth J, Reiber J, Bruschke A Bruis B, et al. Diet, lipoproteins and the progression of Bruis B, et al. Diet, lipoproteins and the progression of Engl f Med 1985; 312: 805-11.

26 Hjermann I, Velve Byre K, Holme I, Leren P. Effect of diet and smoking intervention on the incidence of coronary heart disease. Lancet 1981; ii: 1303-10.

27 Knottnerus J, Swaen G, Slangen J, Volovics A, Durinck J. Haematologic parameters as risk factors for cardiac infarction, in an occupational health care setting. 7 Clin Epidemiol 1988; 41: 67-74.

28 Mellström D, Rundgren $\AA$. Long term effects after partial gastrectomy in elderly men: a longitudinal population study of men between 70 and 75 years of age. Scand 7 Gastroenterol 1982; 17: 433-9.

29 Hirohata T. Mortality from gastric cancer and other causes after medical or surgical treatment for gastric ulcer. $\mathcal{F}$ Natl Cancer Inst 1968; 41: 895-908.

30 Lee S, Iida M, Yao T, Shindo S, Fujishima M, Okabe $H$. Long term follow-up of 2529 patients with gastric and duodenal ulcer: survival rate and causes of death. Gastroenterology 1988; 94: 381-6.

31 Viskum K. Ulcer, attempted suicide and suicide. Acta Psychiat Scand 1975; 51: 221-7.

32 Helsingen $N$, Hillestad $L$. Cancer development in the gastric stump after partial gastrectomy for ulcer. Ann Surg 1956; 143: 173-9.

33 Caygill C, Hill M, Kirkham J, Northfield T. Mortality from gastric cancer following gastric surgery for peptic ulcer. Lancet 1986; i: 929-31.

34 Lewis J, Woods M. Gastric carcinoma in patients with unoperated duodenal ulcer disease. Am f Gastroenterol 1982; 77: 368-73.

35 Norfleet $R$, Johnson S. Strange bedfellows: duodenal ulcer and cancer of the stomach. $\mathcal{F}$ Clin Gastroenterol 1989; 11 : 382-5.

36 Hole D, Quigley E, Gillis C, Watkinson G. Peptic ulcer and cancer: an examination of the relationship between chronic peptic ulcer and gastric carcinoma. Scand $\mathscr{f}$ Gastroenterol 1987; 22: 17-23.

37 Mack T, Yu M, Hanish R, Henderson B. Pancreas cancer and smoking, beverage consumption, and past medical and smoking, beverage consumption, and

38 Carter D. Cancer after peptic ulcer surgery. Gut 1987; 28: 921-30.

39 Cameron H, McGoogan E. A prospective study of 1152 hospital autopsies: I. Inaccuracies in death certification. $\mathcal{f}$ Pathol 1981; 133: 273-83.

40 Stalsberg H, Taksdal S. Stomach cancer following gastric surgery for benign conditions. Lancet 1971; ii: 1175-9.

1 Watt C, Patterson C, Kennedy T. Late mortality after vagotomy and drainage for duodenal ulcer. $B M F$ 1984; 288 : 1335-8.

42 Adami HO, Bergström R, Nyren O, Forhaug K, Gustavsson $S$, Lööf L, Nyberg A. Is duodenal ulcer really a psychosomatic disease? A population-based case-control study. Scand $\mathcal{f}$ Gastroenterol 1987; 22: 889-96. 